ASTOLFI, A. C. M. N.; MOTA, L. J. S.; PONTES, M. S.; CLEMENTE, L. Z.; SANTIAGO, E. F.; CARVALHO, L. A.; MOTTA, I. S. Morphological analysis and accumulation of nutrients in Peltophorum dubium (Spreng.) Taub. seedlings produced in organic substrates with different proportions. Revista de Agricultura Neotropical, Cassilândia-MS, v. 7, n. 3, p. 29-38, jul./set. 2020. ISSN 2358-6303.

\title{
Morphological analysis and accumulation of nutrients in Peltophorum dubium (Spreng.) Taub. seedlings produced in organic substrates with different proportions
}

\author{
Angelica Christina Melo Nunes Astolfi ${ }^{1}$, Lucas Junior da Silva Mota ${ }^{2}$, Montcharles da Silva \\ Pontes $^{2}$, Leyzinara Zenteno Clemente ${ }^{1}$, Etenaldo Felipe Santiago ${ }^{2}$, Laércio Alves de \\ Carvalho $^{2}$, Ivo de Sá Motta ${ }^{3}$
}

${ }^{1}$ Universidade Federal de Mato Grosso do Sul, Campus Campo Grande, Campo Grande, Mato Grosso do Sul, Brasil. E-mail: angelchrismelo@gmail.com, leyzinara@gmail.com

${ }^{2}$ Universidade Estadual de Mato Grosso do Sul, Campus Dourados, Dourados, Mato Grosso do Sul, Brasil. E-mail: lucasjrr000@gmail.com,montcharles.pontes@gmail.com, felipe@uems.br, laercio@uems.br

${ }^{3}$ Embrapa Agropecuária Oeste, Dourados, Mato Grosso do Sul, Brasil. E-mail: ivo.motta@embrapa.br

Received: 27/11/2019; Accepted: 30/04/2020.

\begin{abstract}
Environmental conservation and regeneration actions must consider plant species that add value by restoring structural and functional aspects of the ecosystem. The forest species, Peltophorum dubium, has several characteristics that make its use viable in projects of restoration of degraded areas, making it necessary to study the species' responses to different cultivation environments. Thus, 500 seeds were selected and sown in vermicompost substrates prepared with different proportions of cattle rumen content (CR) and sugarcane bagasse (SB) (V1 - 60\% CR x 40\% SB / V2 - 50\% CR x $50 \%$ SB / V3 - 40\% CR x 60\% SB / V4 - 70\% CR x 30\% SB) and in an commercial substrate (Plantmax ${ }^{\circledR}$ ). At 79 days after sowing, 20 seedlings per treatment were removed; they were weighed and measured, resulting in growth, dry matter, and vigor data. The vermicompost substrates were sent to the chemical analysis laboratory to determine their chemical composition. The data were submitted to normality analysis. Analysis of variance was performed for normal data and the Kruskal Wallis test for data that did not show normality. The means or medians were compared using the Tukey test at a $5 \%$ probability level. Based on the results related to the growth and vigor of $P$. dubium seedlings, it is possible to state that the productive potential of the species was higher in the vermicompost substrates.
\end{abstract}

Keywords: Peltophorum dubium (Spreng.) Taub., native species, reforestation, environmental restoration.

\section{Análise morfológica e acúmulo de nutrientes em mudas de canafístula Peltophorum dubium (Spreng.) Taub. produzidas em substratos orgânicos com diferentes proporções}

\section{RESUMO}

Ações de conservação e regeneração ambiental devem considerar espécies que agreguem valor restabelecendo aspectos estruturais e funcionais do ecossistema. A espécie florestal Canafístula (Peltophorum dubium) apresenta diversas características que tornam seu uso viável em projetos de restauração de áreas degradadas, tornando necessário o estudo das respostas da espécie a diferentes meios de cultivo. Assim, selecionamos 500 sementes que foram plantadas em substratos vermicompostos preparados em diferentes proporções de conteúdo ruminal bovino (CR) e bagaço de canade-açúcar (BC) (V1 - 60\% CR x 40\% BC/ V2 - 50 \% CR x 50 \% BC / V3 - 40\% CR x 60\% BC / V4 -70\% CR x 30\% $\mathrm{BC})$ e comercial $\left(\right.$ Plantmax $\left.^{\circledR}\right)$. Aos 79 dias após a semeadura, foram retiradas 20 mudas por tratamento, que foram pesadas e medidas, resultando nos dados de crescimento, biomassa e vigor. Os substratos vermicompostos foram enviados para o laboratório de análises de solos para determinação da composição nutricional. Os dados resultantes foram submetidos à análise de normalidade, de variância (Anova - dados com normalidade), Kruskal Wallis (dados não normais), sendo as médias ou medianas comparadas por meio do teste de Tukey, com 5\% de significância nas análises. Com base nas respostas relacionadas ao crescimento e vigor das mudas de $P$. dubium, é possível afirmar que o potencial produtivo da espécie foi superior nos tratamentos vermicompostos.

Palavras-chave: Peltophorum dubium (Spreng.) Taub., espécies nativas, reflorestamento, restauração ambiental. 


\section{Introduction}

Agricultural and livestock expansion over areas with native forest cover in the Cerrado has historically been associated with environmental degradation and loss of biological diversity (Alho and Martins, 1995; Cunha et al., 2008). Alternatives for mitigating the impacts resulting from the use and occupation of land imply the adoption of practices supported by the sustainability idea, among which are included the use of organic waste and the production of seedlings of native species for environmental restoration purposes (Cotta et al., 2015; Brancalion et al., 2010). For the success of such actions, it is necessary to know the techniques of production and management of seedlings using species that add value by restoring structural and functional aspects of the ecosystem, which implies the use of good quality inputs and seedlings (Oliveira et al., 2016).

The forest species Peltophorum dubium has several characteristics that make its use viable in projects of restoration of degraded areas. Among these characteristics is the good production of seeds from their parent plants, rapid growth, and rusticity; also, the fact that they are heliophytes, which can be found occupying clearings, edges of forests and colonizing pasture areas, make them suitable for use in mixed reforestation projects of degraded areas of permanent preservation (Lorenzi, 1992; Carnevali et al., 2016). However, for the success of reforestation actions, it is necessary to master production techniques and management of seedlings of native species, which requires knowledge of the responses of different plant species to different cultivation media, since the demands Nutritional factors vary between species.

In the production of seedlings, it is also important to consider substrates that use organic residues in their composition, taking advantage of materials that would otherwise become environmental liabilities. In Mato Grosso do Sul, for example, a significant amount of cattle rumen content and sugarcane bagasse is generated, resulting from the livestock and sugar and alcohol production chains (IBGE, 2016; Biosul, 2016). Even though sugarcane bagasse has become a noble residue, being used in the production of second-generation alcohol (Catolico et al., 2015), new alternatives for its use are important, including the composition of substrates when associated other residues such as rumen content.

Among the forms of stabilization that can be used to produce these materials, vermicomposting stands out, which changes quantitatively and qualitatively the humic substances in organic materials, slow mineralization and releases nutrients more gradually in production systems (Martinez, 1998; Chaoui et al., 2003; Carneiro, 1995). Although the biosolid, the final product of vermicomposting, gathers mineral elements that can be absorbed by plants, the physical and chemical properties of this product may vary according to the proportions of the organic matter sources used in the process.

In general, during composting, it is important to balance the sources of the raw materials that are rich in organic and mineral nutrients, but have a $\mathrm{C}: \mathrm{N}$ ratio favorable to the metabolism of biodigester organisms (Atiyeh et al., 2001; Valente et al., 2008). The C:N ratio ranges during the composting process, allowing for its monitoring and definition of the bio-stabilization. In the production of organic substrates, it is essential to define the best initial and final proportions, including high and low $\mathrm{C}: \mathrm{N}$ ratios. Initial $\mathrm{C}: \mathrm{N}$ ratio from $25: 1$ to $30: 1$ is described as ideal, and after maturation, that is, with the production of biosolids, the ideal final ratio is 10:1 (Kiehl, 2004; Valente et al., 2008). Therefore, studies that evaluate the best formulations are essential, based, for example, on the growth performance of plants.

Information about the quality of the cultivation substrate can be obtained, for example, by analyzing the characteristics of the seedlings, such as morphological traits, including responses related to growth and the allocation of nutrients in plant organs. Analyses such as leaf area and root surface area can indicate changes in response to changes in environmental conditions (Harper et al., 1991). The dry matter gain data are also crucial information in understanding the interaction of the plant with its development environment (Fonseca and Condé, 1994; Barcelos et al., 2007; Fontes et al., 2005).

Thus, considering the economic and ecological importance of $P$. dubium and its wide use in restoration projects of degraded areas, studies that contribute to the mastery of seedling production techniques are essential. In this sense, the following hypotheses were tested: $1 . P$. dubium plants respond to the addition of different proportions of organic sources in the composition of the cultivation substrate; 2 . The use of biosolids based on cattle rumen content and sugarcane bagasse is feasible for the $P$. dubium seedlings production. Given the above, the study aimed to analyze the morphometric responses of young $P$. dubium seedlings grown in alternative organic substrates to produce seedlings with high vigor.

\section{Material and Methods}

\subsection{Experiment}

\subsubsection{Study area}

The study was carried out at the Ecology Laboratory of the Center for Studies in Natural Resources, of the Mato Grosso do Sul State University (CERNA-UEMS), in Dourados, MS. The local climate is classified by the international Köppen system as Cwa - Mesothermal Humid, characterized by average annual precipitation of $1400 \mathrm{~mm}$. 


\subsubsection{Obtaining the Substrate}

The vermicomposts used to produce organic substrates were obtained in partnership with Embrapa Agropecuária Oeste (CPAO). The substrates used in this study included a mixture of cattle rumen content (CR) and sugarcane bagasse (SB). They were produced through the vermicomposting process on windrows with different concentrations between cattle rumen content (CR) and sugarcane bagasse (SB), using the Eudrilus eugeniae earthworm species. The residues were subjected to vermicomposting at concentrations of $60 \%$ CR $x 40 \%$ SB in the substrate V1, 50\% CR x 50\% SB in $\mathrm{V} 2,40 \% \mathrm{CR} \times 60 \% \mathrm{SB}$ in $\mathrm{V} 3$ and $70 \% \mathrm{CR} \times 30 \% \mathrm{SB}$ in V4. The commercial substrate (Plantmax ${ }^{\circledR}$ ) was used as a control treatment. The vermicompost substrates were sent to the chemical analysis laboratory (Solanálise) to determine their chemical properties (Table 1).

\subsubsection{Seed processing}

The ripe fruits of Peltophorum dubium were collected from different parent plants (over twelve) occurring in fragments of vegetation and legal reserves in Dourados, MS, to guarantee the genetic viability of the material. The fruits were opened manually for removal seeds, being selected those with no signs of damage by pathogens or predators, as well as those of reduced size or with defects. The seeds, after processing, were placed in sealed brown paper bags and kept stored in a refrigerated place until the moment of use, obeying the storage standards for later viability.

Seeds were selected (500 seeds), and chemical scarification with sulfuric acid $\left(\mathrm{H}_{2} \mathrm{SO}_{4}\right)$ was performed to overcome the dormancy. Before the scarification process, the seeds were washed in distilled water to remove particles of dust and debris, and after they were taken to dry at room temperature. After dried, the seeds were immersed in sulfuric acid for 15 minutes, washed with running water, and then with distilled water. The seeds that showed signals of soaking were chosen for sowing.

\subsubsection{Treatments and sowing}

The experiment consisted of four vermicompost substrates (V1, V2, V3, and V4) and the Control treatment, composed of a commercial substrate (Plantmax ${ }^{\circledR}$ ). It was carried out in a greenhouse that had a transparent PVC cover, with $50 \%$ shading and automated irrigation. The soaked seeds were sown in plastic tubes with a volume of $290 \mathrm{~cm}^{3}$, and each tube received a seed that was deposited manually at around $1.0 \mathrm{~cm}$ depth. Each treatment consisted of four replications of 25 seeds. The experimental design was completely randomized. All seedling development stages, until the evaluation, occurred in the same cultivation environment, with no need for thinning.

\subsection{Evaluations}

\subsubsection{Growth}

At 79 days after sowing (DAS), five seedlings per replications were removed, at random, totaling 20 seedlings per treatment. The seedlings were washed with running water to remove the substrate. The following variables were evaluated: stem diameter (SD), with the aid of a digital caliper, expressed in $\mathrm{mm}$, and the plant height $(\mathrm{PH})$ and root length $(\mathrm{CR})$, measured with the aid of a millimeter ruler, with the data expressed in $\mathrm{cm}$.

Table 1. Chemical properties of the vermicompost substrates and control substrate (Plantmax $\left.{ }^{\circledR}\right)$.

\begin{tabular}{|c|c|c|c|c|c|}
\hline \multirow{2}{*}{ Nutrients } & \multicolumn{5}{|c|}{ Substrates } \\
\hline & $\begin{array}{c}\mathbf{V 1} \\
(60 \% \mathrm{CR} x \\
40 \% \mathrm{BC})\end{array}$ & $\begin{array}{c}\mathbf{V 2} \\
(50 \% \mathrm{CR} x \\
50 \% \mathrm{BC})\end{array}$ & $\begin{array}{c}\mathbf{V 3} \\
(40 \% \mathrm{CR} x \\
60 \% \mathrm{BC})\end{array}$ & $\begin{array}{c}\mathbf{V 4} \\
(70 \% \mathrm{CR} x \\
30 \% \mathrm{BC})\end{array}$ & Control \\
\hline $\mathrm{N}(\mathrm{g} / \mathrm{kg})$ & 12 & 11.20 & 11.40 & 11.03 & \\
\hline $\mathrm{P}(\mathrm{g} / \mathrm{kg})$ & 3.36 & 2.98 & 3.19 & 2.93 & \\
\hline $\mathrm{K}(\mathrm{g} / \mathrm{kg})$ & 2 & 2.0 & 2.0 & 1.0 & \\
\hline $\mathrm{Ca}(\mathrm{g} / \mathrm{kg})$ & 7.35 & 6.05 & 5.90 & 5.10 & \\
\hline $\mathrm{Mg}(\mathrm{g} / \mathrm{kg})$ & 1.55 & 1.45 & 1.45 & 1.35 & \\
\hline $\mathrm{S}(\mathrm{g} / \mathrm{kg})$ & 14.93 & 14.88 & 13.02 & 13.48 & \\
\hline $\mathrm{C}(\mathrm{g} / \mathrm{kg})$ & 135 & 130 & 147 & 123 & \\
\hline Organic matter $(\mathrm{g} / \mathrm{kg})$ & 233 & 224 & 254 & 212 & \\
\hline $\mathrm{Cu}(\mathrm{mg} / \mathrm{kg})$ & 160 & 140 & 100 & 110 & \\
\hline $\mathrm{Zn}(\mathrm{mg} / \mathrm{kg})$ & 170 & 150 & 150 & 160 & \\
\hline $\mathrm{Fe}(\mathrm{mg} / \mathrm{kg})$ & 118.250 & 133.500 & 114.250 & 130.000 & \\
\hline $\mathrm{Mn}(\mathrm{mg} / \mathrm{kg})$ & 1150 & 1260 & 1080 & 1010 & \\
\hline $\mathrm{B}(\mathrm{mg} / \mathrm{kg})$ & 12.38 & 11.47 & 11.03 & 10.35 & \\
\hline Moisture (\%) & 6.70 & 9.29 & 11.50 & 4.57 & \\
\hline $\mathrm{pH}$ & 5.40 & 5.30 & 5.60 & 5.80 & 5.50 \\
\hline
\end{tabular}




\subsubsection{Leaf and root area}

The roots and compound leaves were scanned in an HP Deskjet device, model F4180. The resulting images were processed using the software ImageJ (leaves) and Safira (roots). The image processing resulted in the leaf area (LA), root surface area (RSA), and weighted diameter of roots (WDR) data.

By obtaining the root diameter, it was possible to calculate the modular area (AM), considering that the larger the modular surface, the larger the root contact surface will be (Santiago and Paoli, 2003).

A cylindrical module was adopted, calculated using the cylinder equation:

$$
2 \cdot \pi \cdot r \cdot(r+h)
$$

Where:

$$
\begin{aligned}
& r=\text { Weighted diameter of roots }(D R) / 2 \\
& h=\text { Adopted height of } 2 \mathrm{~mm} \\
& \pi=\text { constant }
\end{aligned}
$$

\subsubsection{Dry matter}

After scanning, the parts were weighed on a precision digital scale from the Sartorius brand, model TE2145, packed in brown paper bags and taken to dry in the Quimis oven at a constant temperature of $65^{\circ} \mathrm{C}$, for seven days, in which the samples were weighed daily, until reach the constant weight.

By weighing the fresh and dry matter of the samples, the shoot dry matter (SDM) and root dry matter (RDM) were obtained. By the sum of SDM and RDM was obtained the total dry matter (TDM). Such data were obtained with the aid of a precision scale.

\subsubsection{Vigor}

From the dry matter data, the Dickson quality index (DQI) was calculated using the formula described by Dickson et al. (1960):

$$
D Q I=\frac{T D M(g)}{P H(\mathrm{~cm}) / S D(\mathrm{~mm})+S D M(g) / R D M(g)}
$$

Where:

$$
\begin{aligned}
& \text { SDM = shoot dry matter; } \\
& \text { RDM = root dry matter; } \\
& \text { TDM = total diameter } \\
& \text { SD = stem diameter }
\end{aligned}
$$

\subsubsection{Nutrients}

The dry matter resulting from the experiment was sent to the chemical laboratory (Solanálise) to analyzing the chemical composition of the nutrients absorbed by the plant to assess the nutritional status and the allocation of plant resources grown in different substrates.

The nutrients present in the dry matter were determined using the following methodologies: a) N - Sulfuric digestion in block digester (micro Kjeldahl); Distillation of nitrogen by vapor-entrainment (Kjeldahl, 1883; Singh et al., 2020);

b) P - K - Ca - Mg - S - B - Cu - Zn - Fe - Mn - Nitricperchloric acid digestion in a block digester (microKjeldahl); Inductively Coupled Plasma - Atomic Emission Spectrometry - ICP-AES (Kjeldahl, 1883; Singh et al., 2020; Hou and Jones, 2000).

\subsubsection{Statistical data analysis}

The results obtained through the analysis of the area, surface, dry matter, final PH and SD, and DQI, from the different treatments, were subjected to preliminary tests. The absence of normality was verified, and nonparametric analysis of variance (Kruskal Wallis) was used, and the medians were analyzed using the Dunnett test. The substrates with different proportions of vermicomposts were also analyzed using regression adjustment, with the aid of the Bioestat 5.0 software.

\section{Results and Discussion}

Differences were found for all the morphological and dry matter variables presented by $P$. dubium plants grown in the different substrates evaluated. The results of the analysis of shoot dry matter, leaf area, and final plant height and stem diameter are shown in Table 2. In all these variables, a difference was found regarding the commercial substrate (control). The lowest values were observed in the commercial substrate (control) when compared to the substrates with different proportions of vermicomposts.

Regarding the shoot development, except for the leaf area (AF), there was no difference among the vermicompost substrates (Table 2). The medians of SDM, PH, and SD from the vermicompost substrates were $83.3 \%, 42.30 \%$, and $38.43 \%$ higher than the commercial substrate (control), respectively. Whereas for LA, the smallest $\left(9.26 \mathrm{~cm}^{2}\right)$ and highest $\left(37.53 \mathrm{~cm}^{2}\right)$ medians were observed in the commercial substrate (control) and V2 substrate, respectively.

The substrate has the purpose of supporting the seedling, being the physical basis for root growth and availability of water and nutrients (Kämpf, 2002). However, the use of some mixtures requires care, as there may be a deficiency of nutrients for the plants due to the unavailability of some elements (Bunt, 1976). These nutrients must be supplied to the plant as a form of fertilization (El-Ramady et al., 2020). In this way, the commercial substrate is free of fertilizer when purchased, and the producer should add the nutrient of interest. The fact that there was no fertilization explains the results observed in the commercial substrate (control) since the nutrients are absent in the commercial substrate, which 
explains the lower results than the vermicompost substrates in all variables.

The fact that the vermicompost substrates do not differ for the SDM, PH, and SD variables suggests a small effect of the proportions on these variables. In some cases, the selection of a substrate type may depend on other factors, such as availability, ease of handling, among other characteristics (Silva et al., 2001). In the present study, other physical parameters, as well as the results regarding the development of roots in the different treatments, may be relevant in defining the best substrate among the substrates evaluated. The results of the analysis of root dry matter, total dry matter, root surface area, modular area, the weighted diameter of roots, and DQI are shown in Table 3.

The results referring to the RDM were statistically similar for all substrates, except for substrate V4, which had better performance and differed significantly from the commercial substrate (control). Maranho and Paiva (2011), evaluating the growth of seedlings of the native species Senna silvestris on different substrates, obtained the best result of RDM in the commercial substrate Plantmax ${ }^{\circledR}$, indicating that the characteristics that provide the good root development found in the commercial substrate, at least in this study, they were also found in the vermicompost substrates, with the highest performance for the V4 substrate.

As for RSA, there was a significant difference between the commercial (control) and vermicompost substrates. Among the vermicompost substrates, the substrate V4 had the worst performance, differing statistically from the substrates V1 and V2, these being the treatments with greater root growth and more branched roots. Behling et al. (2018), studying the relationship between shoot and roots in teak plants, concluded that there are significant, linear and potential relations between the aerial part and the roots of the species, and that leaf area (LA) is a good estimator of the root surface area of teak plants, with the photosynthetic rate per unit of leaf area modulated by the root system. The results of this study indicate the same pattern for $P$. dubium plants, with higher results of LA in vermicompost substrates than the commercial substrate (control). Also, with the statistical difference between V4 and V1 substrates for both variables.

Regarding MA, there was a statistical difference between commercial (control) and V1 substrates. The highest value of this variable was found in the commercial substrate (control). As for WDR, there was no statistical difference between the vermicompost substrates. However, the V1 substrate differed from the commercial substrate (control). The increase in root diameter is related to the physical characteristics of the substrate, and this characteristic increases the penetration capacity of the roots in compacted soils. The increase in diameter occurs when the soil pore diameter is larger than the root diameter, which may result in a decrease in the volume of soil to be explored by the roots (Silva et al., 2002; Dolan et al., 1992). In the present study, the physical properties of the substrates are not presented, although differences have been found between them. Studies on compaction on vermicompost substrates are important, especially those with a high quantity of cattle rumen content.

Table 2. Shoot dry matter (SDM), leaf area (LA), and final plant height (PH) and stem diameter (SD) of $P$. dubium seedlings grown in vermicompost substrates containing different proportions of cattle rumen content (CR) and sugarcane bagasse (SB), V1 (60\% CR x $40 \%$ SB), V2 (50\% CR x 50\% SB), V3 (40\% CR x 60\% SB), V4 (70\% CR x 30\% SB), and in a commercial substrate - Plantmax ${ }^{\circledR}$ (control).

\begin{tabular}{ccccc}
\hline Substrates & SDM $(\mathbf{g})$ & LA $\left(\mathbf{c m}^{2}\right)$ & PH $(\mathbf{c m})$ & SD $(\mathbf{m m})$ \\
\hline Control & $0.08 \mathrm{~b}$ & $9.26 \mathrm{c}$ & $6.76 \mathrm{~b}$ & $1.65 \mathrm{~b}$ \\
V4 & $0.45 \mathrm{a}$ & $27.22 \mathrm{~b}$ & $11.07 \mathrm{a}$ & $2.71 \mathrm{a}$ \\
V3 & $0.52 \mathrm{a}$ & $30.54 \mathrm{ab}$ & $11.02 \mathrm{a}$ & $2.56 \mathrm{a}$ \\
V2 & $0.49 \mathrm{a}$ & $37.53 \mathrm{a}$ & $12.11 \mathrm{a}$ & $2.77 \mathrm{a}$ \\
V1 & $0.46 \mathrm{a}$ & $31.89 \mathrm{ab}$ & $12.07 \mathrm{a}$ & $2.70 \mathrm{a}$ \\
\hline
\end{tabular}

Means followed by different letters in the columns indicate a significant difference $(\mathrm{p}<0.05)$ between substrates.

Table 3. Root dry mass (RDM), total dry mass (TDM), root surface area (RSA), modular area (MA), weighted diameter of roots (WDR), root length (RL) and Dickson seedling quality index (DQI) of $P$. dubium seedlings grown in vermicompost substrates containing different proportions of cattle rumen content (CR) and sugarcane bagasse (SB), V1 (60\% CR x 40\% SB), V2 (50\% CR x $50 \% \mathrm{SB}), \mathrm{V} 3(40 \% \mathrm{CR} \times 60 \% \mathrm{SB}), \mathrm{V} 4(70 \% \mathrm{CR} \times 30 \% \mathrm{SB})$, and in a commercial substrate - Plantmax ${ }^{\circledR}$ (control).

\begin{tabular}{cccccccc}
\hline Substrates & RDM $(\mathbf{g})$ & TDM $(\mathbf{g})$ & RSA $\left(\mathbf{m m}^{2}\right)$ & MA $\left(\mathbf{m m}^{2}\right)$ & WDR $(\mathbf{m m})$ & RL $(\mathbf{c m})$ & DQI \\
\hline Control & $0.08 \mathrm{~b}$ & 3.38 & $3,179.8 \mathrm{c}$ & $2.58 \mathrm{~b}$ & $0.31 \mathrm{a}$ & $15.19 \mathrm{a}$ & 0.87 \\
V4 & $0.15 \mathrm{a}$ & 10.72 & $6,754.92 \mathrm{~b}$ & $2.20 \mathrm{ab}$ & $0.28 \mathrm{ab}$ & $13.24 \mathrm{~b}$ & 1.67 \\
V3 & $0.14 \mathrm{ab}$ & 11.90 & $7,389.54 \mathrm{ab}$ & $2.26 \mathrm{ab}$ & $0.28 \mathrm{ab}$ & $13.47 \mathrm{~b}$ & 1.70 \\
V2 & $0.13 \mathrm{ab}$ & 12.91 & $9,416.72 \mathrm{a}$ & $2.23 \mathrm{ab}$ & $0.28 \mathrm{ab}$ & $13.65 \mathrm{~b}$ & 1.75 \\
V1 & $0.09 \mathrm{ab}$ & 11.60 & $10,439.44 \mathrm{a}$ & $1.95 \mathrm{ac}$ & $0.27 \mathrm{~b}$ & $14.04 \mathrm{~b}$ & 1.36 \\
\hline
\end{tabular}

Means followed by different letters in the columns indicate a significant difference $(\mathrm{p}<0.05)$ between substrates. 
Root growth in extension and branching, as observed in vermicompost substrates, reflects the best nutritional conditions. On the other hand, the growth in the extension of the root, as observed in the commercial substrate, can be seen as a strategy to increase the exploration area and, consequently, the absorption potential in conditions of water and nutrient deficiency (Santos and Carlesso, 1998). In other words, little branched root systems, with high growth in length associated with the largest diameter and modular area, such as observed in the commercial substrate, may reflect on responses to nutritional deficiency.

Fernandes et al. (2013), studying nutritional deficiencies of macronutrients and sodium in peach palm seedlings, observed that seedlings deficient in $\mathrm{P}$ showed an increase in the length of the primary roots and a smaller amount of root hairs. B deficiency, in turn, can reduce the production of total and thin roots, cause thickening of the roots and short branches (Lima Filho and Malavolta, 1997; Salvador et al., 1999; Pinho et al., 2008). Well-developed roots represent an increase in the dry matter production capacity of plants, as they are responsible for the water and nutrients uptake, besides the storage of carbohydrates and proteins responsible for the production and continuity of the plant. Therefore, in vermicompost substrates, the more branched roots potentiated not only the absorption of nutrients from the environment but also the transport to shoot, as well as the storage of photoassimilates from the shoot (Giacomini et al., 2005).

About the TDM, the best results were observed for the vermicompost substrates. The best performance was verified in the substrate $\mathrm{V} 2$, followed by the substrates V3, $\mathrm{V} 4$, and V1; and, the gains related to TDM in seedlings produced with vermicompost substrates were around $70 \%$ higher than those produced in the commercial substrate (control). Such results are an indication of the better performance of vermicompost substrates, in general, in the production of $P$. dubium seedlings, since TDM indicates the rusticity and the hardening of these seedlings that will be more resistant to the adverse conditions of the field, and it will result in higher survival rate (Gomes and Paiva, 2006; Gomes et al., 2002).

Regarding the DQI, the vermicompost substrates were, on average, about $46.29 \%$ higher than the commercial substrate (control), with the best result observed in the vermicompost substrate V2, followed by the substrates V3, V4 and V1. According to Hunt (1990), the DQI value must be greater than 0.2 ; thus, the plants in all substrates reached the value recommended by the author; however, the higher the DQI value, the better the seedling quality. Therefore, the DQI results indicate the greater efficiency of vermicompost substrates in the expression of the productive potential of $P$. dubium seedlings, resulting in more vigorous plants.
The values related to the DQI of the seedlings produced in the vermicompost substrates were, on average, about $82 \%$ higher than the values observed in the study by Dutra et al. (2013), who evaluated alternative substrates, Bioplant ${ }^{\circledR}$ and sugarcane bagasse (BC) for the production of $P$. dubium seedlings. The authors found, as the best result, DQI of 0.28 for seedlings grown in the substrate containing only the Bioplant ${ }^{\circledR}$, and the worst result $(0.09)$ was found in the substrate containing only sugarcane bagasse SB. The difference between the DQI values of the P. dubium seedlings in this experiment and those produced by Dutra et al. (2013) may not be due to the different treatments, because despite being the same forest species, the genetic variability factor cannot be ruled out, since secondary species have intermediate gene flow, with a moderate genetic divergence between their populations (Engel and Parrota, 2003).

For a better understanding of the $\mathrm{CR}$ proportions effects in the composition of the vermicompost substrates, the variables for which regression adjustment was identified are shown in Figure 1.

The average proportion of $\mathrm{CR}$ in the composition of the organic substrate based on the maximum points of the $\mathrm{Y}$ values of shoot dry matter (SDM), total dry matter (TDM), leaf area (LA), and plant height (PH) was $46.81 \%$, suggesting that this is the best proportion for the formulation of the substrate for $P$. dubium seedlings production from vermicompost based on cattle rumen content (CR) and sugarcane bagasse (SB).

Besides the morphological and growth data, the evaluation of plant performance to determine the best substrates can also be obtained through the analysis of identification and quantification of nutrients present in the dry matter of the plants (Table 4). The result of the chemical analysis of macro and micronutrients (Table 4) showed that most nutrients ( $\mathrm{P}, \mathrm{K}, \mathrm{Mg}, \mathrm{S}, \mathrm{Cu}, \mathrm{Zn}, \mathrm{Mn}, \mathrm{B}$, and $\mathrm{Fe}$ ) are allocated in greater quantity in the root. At the same time, the $\mathrm{N}$ and $\mathrm{Ca}$ are present in greater amounts in the aerial part. Except for the commercial substrate, which had a higher content of Mn in shoot than roots. Among the nutrients present in the root and shoot in the different substrates, the results referring to $\mathrm{P}, \mathrm{K}$, $\mathrm{Mg}, \mathrm{Mn}, \mathrm{Fe}$, and $\mathrm{Cu}$ are worth mentioning.

Silva et al. (2011), studying the behavior of $P$. dubium, Enterolobium timbouva, and Anadenanthera sp. in response to copper doses, stated, among other things, that $P$. dubium has a tendency to store copper $(\mathrm{Cu})$ in the roots, and had low translocation to the shoot. In this context, the observed results suggest a behavior similar to the study by Silva et al. (2011), showing absorption and translocation of $\mathrm{Cu}$ ions with the same pattern, with greater allocation in the roots. This characteristic of accumulating metals in the roots and not translocate to the aerial part is indicative of the activation of regulatory 
mechanisms of translocation in situations, for example, of the excess of contaminants in the soil (Antosiewicz, 1992), which shows the potential of the species not only for reforestation but also for phytoremediation, since plants with this characteristic have a high capacity to extract contaminating elements from the environment (Chen et al., 2005).

Regarding $\mathrm{P}$, the results indicate that the presence of this element was about $55 \%$ greater in the root of the seedlings grown in the commercial substrate (control) than the average found in the roots of seedlings grown in vermicompost substrates. This fact may be related to the statement by Grant et al. (2001), that the plant can retain a supply of $\mathrm{P}$ in the roots to satisfy its needs in conditions where there is low availability of this nutrient.

The content of $\mathrm{K}$ allocated in the shoot was similar for all treatments, while in the roots, it was higher in the seedlings grown in the commercial substrate. Silva et al. (2002) state that the increase in the root diameter, as occurred in seedlings grown in the commercial substrate (control), can favor the absorption of $\mathrm{K}$ per unit of root length in a compacted medium. Thus, the presence of higher levels of this nutrient in the commercial substrate (control) may be related to the physical characteristics of the substrate.

As for $\mathrm{Mg}, 15$ to $30 \%$ of $\mathrm{Mg}$ present in plants is associated with the chlorophyll molecule (Barker and Pilbeam, 2007); the results of the analyzes indicate, however, the presence of $\mathrm{Mg}$ in higher quantities in the dry matter of the commercial substrate (control), although the most vigorous seedlings were produced with the vermicompost substrates. Among the properties of $\mathrm{Mg}$, the most important is the solubility of its compounds, and its abundance suggests a multiplicity of functions, among them the transfer of phosphate (Novais et al., 2007). Thus, the higher $\mathrm{Mg}$ content in the commercial substrate (control) may be a response to the nutritional imbalance of this substrate, which has a $\mathrm{P}$ deficiency, aiming at the transfer of this nutrient, which, in a situation of low availability is stored in the root.

The $\mathrm{Fe}$ content was higher in vermicompost substrates, both in the shoot and in the roots, a fact that, according to Novais et al. (2007), may be related to the organic matter content (OM) that promotes the best use of Fe by plants, and the presence of humic substances capable of forming chelates.
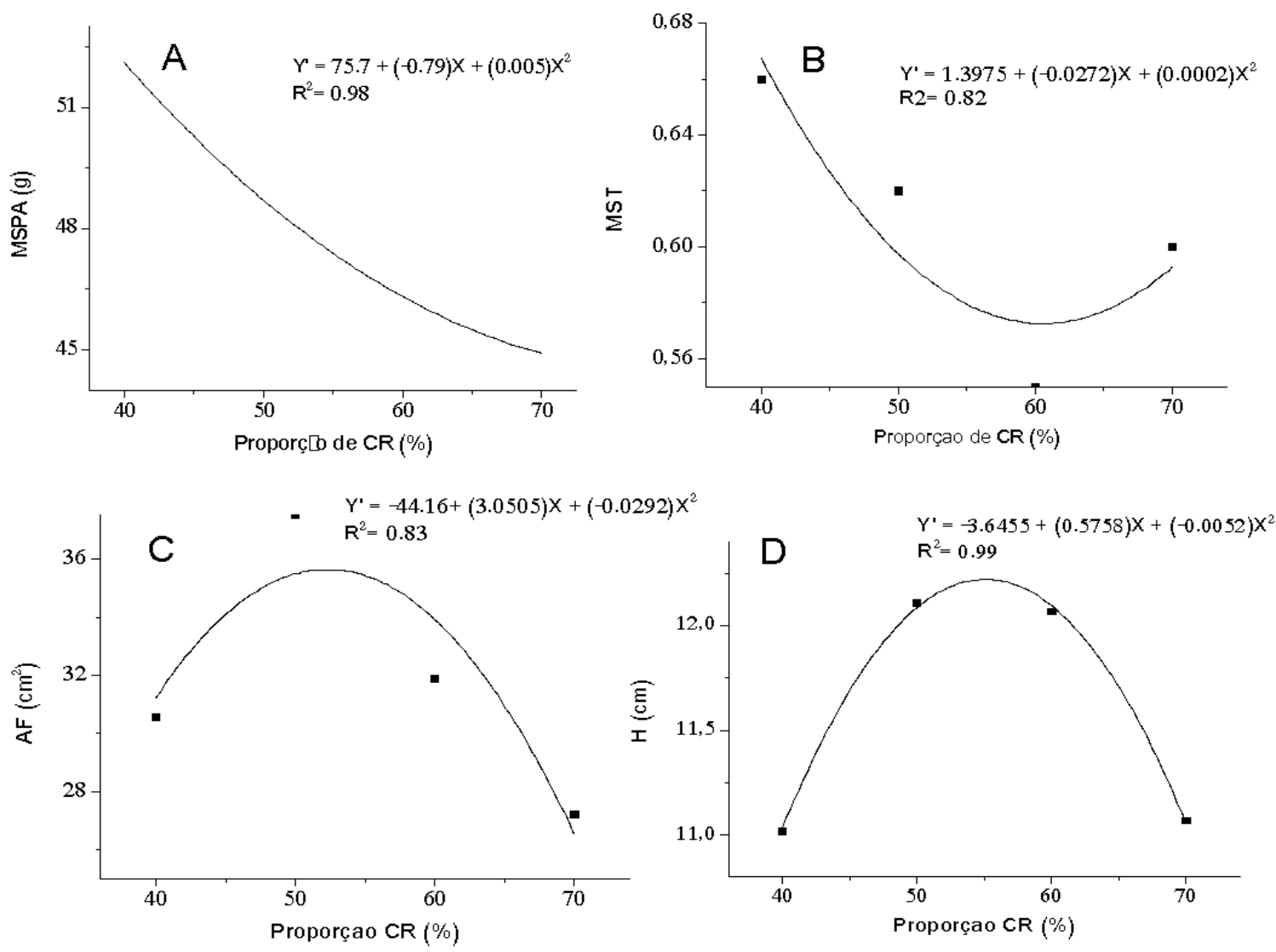

Figure 1. Effect of the proportions of cattle rumen content $(\mathrm{CR})$ in the composition of the organic substrate on the shoot dry matter (SDM), total dry matter (TDM), leaf area (LA), and final plant height (PH) of P. dubium seedlings grown in vermicompost substrates containing different proportions of cattle rumen content (CR) and sugarcane bagasse (SB), V1 (60\% CR x 40\% SB), V2 (50\% CR x $50 \% \mathrm{SB}), \mathrm{V} 3(40 \% \mathrm{CR} \times 60 \% \mathrm{SB})$, and V4 (70\% CR x 30\% SB). 
Table 4. Macro and micronutrient content in $P$. dubium seedlings produced in vermicompost substrates in different proportions of cattle rumen content (CR) and sugarcane bagasse (BC), and in the commercial substrate - Plantmax ${ }^{\circledR}$ (control).

\begin{tabular}{|c|c|c|c|c|c|}
\hline \multirow[b]{2}{*}{ Nutrients } & \multicolumn{5}{|c|}{ Nutrient content - Root } \\
\hline & $\begin{array}{c}\mathbf{V 1} \\
(60 \% \mathrm{CR} x \\
40 \% \mathrm{BC})\end{array}$ & $\begin{array}{c}\text { V2 } \\
(50 \% \mathrm{CR} x \\
50 \% \mathrm{BC})\end{array}$ & $\begin{array}{c}\mathbf{V 3} \\
(40 \% \mathrm{CR} x \\
60 \% \mathrm{BC})\end{array}$ & $\begin{array}{c}\text { V4 } \\
(70 \% \mathrm{CR} x \\
30 \% \mathrm{BC})\end{array}$ & Control \\
\hline $\mathrm{P}(\mathrm{g} / \mathrm{kg})$ & 1.70 & 1.39 & 1.69 & 1.77 & 3.65 \\
\hline $\mathrm{N}(\mathrm{g} / \mathrm{kg})$ & 10.32 & 9.48 & 9.78 & 11.70 & 6.24 \\
\hline $\mathrm{K}(\mathrm{g} / \mathrm{kg})$ & 17.77 & 14.87 & 18.88 & 17.83 & 25.08 \\
\hline $\mathrm{Ca}(\mathrm{g} / \mathrm{kg})$ & 4.97 & 4.52 & 4.51 & 4.90 & 4.46 \\
\hline $\operatorname{Mg}(\mathrm{g} / \mathrm{kg})$ & 2.09 & 1.64 & 2.02 & 1.66 & 2.69 \\
\hline $\mathrm{S}(\mathrm{g} / \mathrm{kg})$ & 1.56 & 1.08 & 1.31 & 1.32 & 2.63 \\
\hline $\mathrm{Cu}(\mathrm{mg} / \mathrm{kg})$ & 8.82 & 8.29 & 9.62 & 7.99 & 5.29 \\
\hline $\mathrm{Zn}(\mathrm{mg} / \mathrm{kg})$ & 18.09 & 16.45 & 19.23 & 15.93 & 27.28 \\
\hline $\mathrm{Mn}(\mathrm{mg} / \mathrm{kg})$ & 18.95 & 21.15 & 20.74 & 11.73 & 5.28 \\
\hline $\mathrm{B}(\mathrm{mg} / \mathrm{kg})$ & 82.73 & 58.40 & 82.16 & 79.16 & 78.04 \\
\hline $\mathrm{Fe}(\mathrm{mg} / \mathrm{kg})$ & 1335.00 & 1660.00 & 1715.50 & 1510.00 & 248.16 \\
\hline \multirow{2}{*}{ Nutrients } & \multicolumn{5}{|c|}{ Nutrient content - Shoot } \\
\hline & $\begin{array}{c}\mathrm{V1} \\
(60 \% \mathrm{CR} x \\
40 \% \mathrm{BC}) \\
\end{array}$ & $\begin{array}{c}\mathbf{V 2} \\
(50 \% \mathrm{CR} x \\
50 \% \mathrm{BC}) \\
\end{array}$ & $\begin{array}{c}\mathbf{V 3} \\
(40 \% \mathrm{CR} x \\
60 \% \mathrm{BC}) \\
\end{array}$ & $\begin{array}{c}\mathbf{V 4} \\
(70 \% \mathrm{CR} x \\
30 \% \mathrm{BC}) \\
\end{array}$ & Control \\
\hline $\mathrm{P}(\mathrm{g} / \mathrm{kg})$ & 1.46 & 1.26 & 1.51 & 1.48 & 2.12 \\
\hline $\mathrm{N}(\mathrm{g} / \mathrm{kg})$ & 13.08 & 12.54 & 11.88 & 12.48 & 8.40 \\
\hline $\mathrm{K}(\mathrm{g} / \mathrm{kg})$ & 11.91 & 11.16 & 11.40 & 11.53 & 10.98 \\
\hline $\mathrm{Ca}(\mathrm{g} / \mathrm{kg})$ & 7.26 & 7.00 & 6.87 & 7.18 & 5.70 \\
\hline $\mathrm{Mg}(\mathrm{g} / \mathrm{kg})$ & 1.54 & 1.61 & 1.70 & 1.62 & 2.28 \\
\hline $\mathrm{S}(\mathrm{g}) / \mathrm{kg}$ & 0.97 & 0.83 & 0.80 & 0.82 & 1.02 \\
\hline $\mathrm{Cu}(\mathrm{mg} / \mathrm{kg})$ & 1.92 & 0.94 & 1.87 & 1.77 & 1.58 \\
\hline $\mathrm{Zn}(\mathrm{mg} / \mathrm{kg})$ & 15.84 & 15.41 & 17.37 & 14.91 & 17.25 \\
\hline $\mathrm{Mn}(\mathrm{mg} / \mathrm{kg})$ & 17.58 & 17.65 & 14.56 & 12.94 & 9.41 \\
\hline $\mathrm{B}(\mathrm{mg} / \mathrm{kg})$ & 53.94 & 53.41 & 54.93 & 53.54 & 51.78 \\
\hline $\mathrm{Fe}(\mathrm{mg} / \mathrm{kg})$ & 129.49 & 110.24 & 102.56 & 119.72 & 74.36 \\
\hline
\end{tabular}

As for Mn, it was observed a higher content in plants grown in vermicompost substrates, both in shoot and roots. The divalent form of $\mathrm{Mn}$ is absorbed in greater abundance by the plant, and this element may accumulate in a humus-rich medium, with $\mathrm{pH}$ equal to or less than 5.5, and high reducing conditions (Novais et al., 2007); conditions that can be found in vermicompost substrates.

The initial condition of nutrients present in the substrates is not constant throughout the experiment, a part is absorbed by the plant, and part is lost in the system through leaching and volatilization processes. The nutrients found in smaller quantities in the $P$. dubium seedlings may have been leached or volatilized, making them unavailable to plants. The unavailability or excess of nutrients in the substrate causes nutritional imbalance, best exemplified by the results of the commercial substrate (control). In contrast, the production of more vigorous $P$. dubium seedlings produced in the vermicompost substrates indicates the better maintenance of the nutritional balance in these substrates.

\section{Conclusions}

In general, the plants of $P$. dubium responded positively to the addition of different proportions of organic sources in the composition of the cultivation substrate, and all vermicompost substrates had better performance than the commercial substrate (control).

The use of substrate based on cattle rumen content and sugarcane bagasse proved to be viable to produce $P$. dubium seedlings. Despite the prominence of the substrate V2 for some variables, including the highest DQI value, and the substrate V3 with high productive potential, the recommended theoretical proportion for the formulation of a substrate to produce $P$. dubium seedlings were $46.81 \%$ of cattle rumen content and $53.19 \%$ of sugarcane bagasse.

It also highlights the importance of evaluating the physical properties of the substrates as an important element in defining the best formulations, as well as the need for further studies that consider the potential of the $P$. dubium species for phytoremediation purposes. 


\section{Bibliographic References}

Alho, C.J.R., Martins, E.S., 1995. Cerrado - impactos do processo de ocupação, in: Alho, C.J.R., Martins, E.S. De grão em grão o Cerrado perde espaço. Brasília, World Wildlife Fund (WWF) e Sociedade de Pesquisas Ecológicas do Cerrado, p. 4766.

Antosiewicz, D.M., 1992. Adaptation of plants to an environment polluted with heavy metals. Acta Societatis Botanicorum Poloniae, 61(2), 281-299.

Atiyeh, R.M., Edwards, C.A., Subler, S., Metzger, J.D., 2001. Pig manure vermicompost as a component of a horticultural bedding plant medium: effects on physicochemical properties and plant growth. Bioresource Technology, 78(1), 11-20.

Barcelos, M.D., Garcia, A., Marciel Junior, V.A., 2007. Análise de crescimento da cultura da batata submetida ao parcelamento da adubação nitrogenada em cobertura, em um Latossolo vermelho-amarelo. Ciência \& Agrotecnologia, 31(1), 21-27.

Barker, A.V., Pilbeam, D.J., 2007. Handbook of Plant Nutrition, first ed. CRC Press, New York.

Behling, M, Felipe, R.T.A, Farias, J.B., Carvalho, G., Neves, J.C.L., 2018. Relações entre parte aérea e raízes em povoamentos de teca. Revista Ceres, 65(6), 463-473.

Biosul. Associação dos Produtores de Bioenergia de Mato Grosso do Sul, 2016. Acompanhamento da safra 2015/2016 produção até 31/março: final de safra. Campo Grande.

Brancalion, P.H.S., Rodrigues, R.R., Gandolfi, S., Kageyama, P.Y., Nave, A.G., Gandara, F.B., Barbosa, L.M., Tabarelli, M., 2010. Instrumentos legais podem contribuir para a restauração de florestas tropicais biodiversas. Revista Árvore, 34(3), 455470 .

Bunt, A.C., 1976. Modern Potting Composts: a manual on the preparation and use of growing media for pot plants, first ed. George Allen \& Unwin, London.

Carneiro, J.G.A., 1995. Produção e controle de qualidade de mudas florestais, primeira ed. Curitiba, UFPR.

Carnevali, N.H.S., Santiago, E.F., Daloso, D.M., Carnevali, T.O., Oliveira, M.T., 2016. Sobrevivência e crescimento inicial de espécies arbóreas nativas implantadas em pastagem degradada. Floresta, 46(2), 277-286.

Catolico, A.C, Oliveira, R, Crivelare, L, Oliveira, A., 2015. Análise de sustentabilidade do etanol $2 \mathrm{~g}$ e bioenergia da cana. Periódico Eletrônico Fórum Ambiental da Alta Paulista, 11(9), 97-112.

Chaoui, H.I., Zibilske, L.M., Ohno, T., 2003. Effects of earthworm casts and compost on soil microbiol activity and plant nutrient availability. Soil Biology and Biochemistry, 35(2), 295-302.

Chen, Y.X., Wang, Y.P., Lin, Q., Luo, Y.M., 2005. Effect of cooper-tolerant rhizosfhere bacteria on mobility of copper in soil and copper accumulation by Elsholtzia splendens. Environment International, 31(6), 861-866.

Cotta, J.A.O., Carvalho, N.L.C., Brum, T.S., Rezende, M.O.O., 2015. Compostagem versus vermicompostagem: comparação das técnicas utilizando resíduos vegetais, esterco bovino e serragem. Engenharia Sanitária e Ambiental, 20(1), 65-78.

Cunha, N.R.S., Lima, J.E., Gomes, M.F.M., Braga, M.J., 2008. A intensidade da exploração agropecuária como indicador da degradação ambiental na região dos Cerrados. Revista de Economia e Sociologia Rural, 46(2), 291-323.

Dickson, A., Leaf, A.L., Hosner, J.F., 1960. Quality appraisal of white spruce and white pine seedling stock in nurseries. Forestry Chronicle, 36(1), 10-13.

Dolan, M.S., Dowdy, R.H., Voorhees, W.B., Johnson, J.F., Bidwell-Schrader, A.M., 1992. Corn phosphorus and potassium uptake in response to soil compaction. Agronomy Journal, 84(4), 639-642.

Dutra, T.R., Massad, M.D., Sarmento, M.F.Q., Oliveira, J.C., 2013. Substratos alternativos e métodos de quebra de dormência para produção de mudas de canafístula. Revista Ceres, 60(1), 72-78.

El-Ramady, H., Olle, M., Eichler-Löbermann, B., Schnug, E., 2020. Towards a new concept of sustainable plant nutrition. Environment, Biodiversity and Soil Security, 4(4), 1-7.

Engel, V.L., Parrota, J.A., 2003. Definindo a restauração ecológica: tendências e perspectivas mundiais, in: Kageyama, P.Y., Oliveira, R.E., Moraes, L.F.D., Engel, V.L., Mendes, F.B.G., (Eds.). Restauração Ecológica de Ecossistemas Naturais. FEPAF, Botucatu, p. 1-26.

Fernandes, A.R., Matos, G.S.B., Carvalho, J.G., 2013. Deficiências nutricionais de macronutrientes e sódio em mudas de pupunheira. Revista Brasileira de Fruticultura, 35(4), 1178 1189.

Fonseca, C.E.L., Condé, R.C.C., 1994. Estimativa da Área Foliar em mudas de Mangabeira (Hancornia speciosa Gom.). Pesquisa Agropecuária Brasileira, 29(4), 593-599.

Fontes, P.C.R., Dias, E.N., Silva, D.J.H., 2005. Dinâmica do crescimento, distribuição de matéria seca na planta e produção de pimentão em ambiente protegido. Horticultura Brasileira, 23(1), 94-99.

Giacomini, A.A., Mattos, W.T., Mattos, H.B., Werner, J.C., Cunha, E.A., Carvalho, D.D., 2005. Crescimento de raízes dos capins aruana e tanzânia submetidos a duas doses de nitrogênio. Revista Brasileira de Zootecnia, 34(4), 1109-1120.

Gomes, J.M., Couto, L., Leite, H.G., Xavier, A., Garcia, S.L.R., 2002. Parâmetros morfológicos na avaliação da qualidade de mudas de Eucalyptus grandis. Revista Árvore, 26(6), 655-664.

Gomes, J.M., Paiva, H.N., 2006. Viveiros florestais (propagação sexuada), terceira ed. Viçosa, UFV.

Grant, C.A., Platen, D.N., Tomaziewicz, D.J., Sheppard, S.C., 2001. A importância do fósforo no desenvolvimento inicial da planta. Informações Agronômicas, 95(1), 01-05.

Harper, J.L., Jones, M., Sackville-Hamilton, N.R., 1991. The evolution of roots and the problems of analysing their behavior, in: Atkinson, D., (Ed.). Plant root growth: an ecological perspective. Blackwell, Oxford, p. 3-22.

Hou, X, Jones, B.T., 2000. Inductively Coupled Plasma/Optical Emission Spectrometry, in: Encyclopedia of Analytical Chemistry. John Wiley \& Sons, Ltd., p. 1-25. 
Hunt, G.A., 1990. Effect of styroblock design and cooper treatment on morphology of conifer seedlings, in: Proceedings of Target Seedling Associations, General Technical Report RM-200. Reforestation, Nurseries \& Genetics Resources, Roseburg, p. 218-222.

IBGE. Instituto Brasileiro de Geografia e Estatística, 2016. Indicadores IBGE - Estatística da Produção Pecuária: setembro de 2016. Rio de Janeiro, IBGE, 45 p.

Kämpf, A.N., 2002. O uso de substrato em cultivo protegido no agronegócio brasileiro, in: Furlani, A.M.C., Bataglia, O.C., Abreu, M.F., Abreu, C.A., Furlani, P.R., Quaggio, J.A., Minami, K., (Eds.). Caracterização, manejo e qualidade de substratos para produção de plantas. Instituto Agronômico, Campinas, p. 1-6.

Kiehl, E.J., 2004. Manual de compostagem: maturação e qualidade do composto, quarta ed. Piracicaba, São Paulo.

Kjeldahl, J., 1883. Neue methode zur bestimmung des stickstoffs in organischen körpern. Fresenius Journal of Analytical Chemistry, 22, 366-382.

Lima Filho, O.F., Malavolta, E., 1997. Sintomas de desordens nutricionais em estévia Stevia rebaudiana (Bert.) Bertoni. Scientia Agricola, 54(1-2), 53-61.

Lorenzi, H., 1992. Árvores brasileiras: manual de identificação e cultivo de plantas arbóreas nativas do Brasil. Nova Odessa, Plantarum.

Maranho, A.S., Paiva, A.V., 2011. Crescimento inicial de mudas de Senna silvestris (vell.) H. S. Irwin \& Barneby cultivadas em diferentes substratos. Revista da Sociedade Brasileira de Arborização Urbana, 6(4), 1-14.

Martinez, A.A., 1998. A grande e poderosa minhoca: manual prático do minhocultor, quarta ed. Funep, Jaboticabal.

Novais, R., Alvarez, V.H.V., Barros, N.F., Fontes, R.L., Cantarutti, R.B., Cantarutti, J.C.L., 2007. Fertilidade do Solo, first ed. Sociedade Brasileira de Ciência do Solo, Viçosa.

Oliveira, M.C., Ogata, R.S., Andrade, G.A., Santos, D.S., Souza, R.M., Guimaraes, T.G., Silva Júnior, M.C., Pereira, D.J.S., Ribeiro, J.F., 2016. Manual de viveiro e produção de mudas: espécies arbóreas nativas do Cerrado. Embrapa Cerrados, Brasília.

Pinho, L.G.R., Monnerat, P.H., Pires, A.A., Marciano, C.R., Soares, Y.J.B., 2008. Distribuição de nutrientes e sintomas visuais de deficiência de boro em raízes de coqueiro-anão verde. Revista Brasileira de Ciência do Solo, 32(6), 2581-2590.

Salvador, J.O., Moreira, A., Muraoka, T., 1999. Sintomas visuais de deficiências de micronutrientes e composição mineral de folhas em mudas de goiabeira. Pesquisa Agropecuária Brasileira, 34(9), 1655-1662.

Santiago, E.F., Paoli, A.A.S., 2003. O aumento em superfície em Adelia membranifolia (Müll. Arg.) Pax \& K. Hoffm. e Peltophorum dubium (Spreng.) Taub., em resposta ao estresse por deficiência nutricional e alagamento do substrato. Revista Brasileira de Botânica, 26(4), 503-513.

Santos, R.F., Carlesso, R., 1998. Déficit hídrico e os processos morfológico e fisiológico das plantas. Revista Brasileira de Engenharia Agrícola e Ambiental, 2(3), 287-294.

Silva, R.F., Lupatini, M., Antoniolli, Z.I., Leal, L.T, Moro Junior, C.A., 2011. Comportamento de Peltophorum dubium (Spreng.) Taub., Parapiptadenia rigida (Benth.) Brenan e Enterolobium contortisiliquum (Vell.) Morong cultivadas em solo contaminado com cobre. Ciência Florestal, 21(1), 103-110.

Silva, R.P., Peixoto, J.R., Junqueira, N.T.V., 2001. Influência de diversos substratos no desenvolvimento de mudas de maracujazeiro azedo (Passiflora edulis Sims f. flavicarpa DEG). Revista Brasileira de Fruticultura, 23(2), 377-381.

Silva, S.R., Barros, N.F., Novais, R.F., Pereira, P.R.G., 2002. Eficiência nutricional de potássio e crescimento de eucalipto influenciados pela compactação do solo. Revista Brasileira de Ciência do Solo, 26(4), 1001-1010.

Singh, P., Singh, R.K., Song, Q.Q., Li, H.B., Yang, L.T., Li, Y.R., 2020. Methods for Estimation of Nitrogen Components in Plants and Microorganisms, in: Gupta, K., (Ed.). Methods in Molecular Biology. Humana, New York, p. 103-112.

Valente, B.S, Xavier, E.G., Morselli, T.B.G.A., Jahnke, D.S., Brum Junior, B., Cabrera, B.R., Moraes, P., Lopes, D.C.N., 2008. Fatores que afetam o desenvolvimento da compostagem de resíduos orgânicos. Archivos de Zootecnia, 58(224), 59-85. 